\title{
POLITICS OF FEMALE IDENTITY IN TRADITIONAL JAVA THROUGH THE PRISM OF PRAMOEDYA A. TOER'S GADIS PANTAI
}

\author{
MUHAMMAD JAUHARI SOFI* \\ Institut Agama Islam Negeri Pekalongan
}

\section{Abstract}

Identity is political rather than natural. It is always influenced by the politics of race, class, gender, religion, education, disability, and so on. This paper examines the complexity of political forces that shape female identity at the beginning of the $20^{\text {th }}$ century Java and the reaction the women show in response to the circumstances where they find themselves, with reference to Pramoedya Ananta Toer's Gadis Pantai. The novel, which is based on the true story of his own grandmother, portrays the life of a practice wife of priyayi, the hereditary governing class of Java. Using interpretive analysis and close reading of the text, the study argues that feudal and patriarchal circumstances help shape female identity in the $20^{\text {th }}$ century Java. Women are doubly discriminated; they find themselves subject to higher powers, i.e. the powers of the feudal lord and the male. However, throughout the novel, the author displays a brandnew female image different from the socially dominant discourses, an image that has qualities of rebellious fervor to trouble the discriminating social category of identity.

Identitas lebih bersifat politis daripada alami. Ia seringkali dipengarubi oleh politik ras, kelas, gender, agama, pendidikan, disabilitas, dan sebagainya. Makalah ini membahas tentang kompleksitas jaring-jaring politik yang turut membentuk identitas perempuan

\footnotetext{
* Corresponding author at: IAIN Pekalongan, Jl. Kusuma Bangsa, Panjang Baru, Pekalongan, Indonesia 51141. E-mail: jauharisofi@gmail.com
} 
Jawa pada awal abad ke-20 dan reaksi kaum perempuan terhadap keadaan diskriminatif yang melingkupi hidup mereka dengan merujuk pada novel Gadis Pantai karya Pramoedya Ananta Toer. Novel yang didasarkan pada kisah nyata dari neneknya tersebut menggambarkan kisah kehidupan seorang istri 'percobaan' dari seorang priyayi, atau kelas bangsawan dalam tradisi Jawa. Dengan menggunakan analisis interpretatif dan pembacaan mendalam atas teks (novel), kajian ini menemukan bahwa budaya feodalisme dan patriarki turut membentuk identitas perempuan Jawa pada awal abad ke-20. Pada saat itu, perempuan Jawa mengalami diskriminasi dua kali lipat sekaligus; mereka harus tunduk pada kekuatan-kekuatan yang lebih tinggi, yaitu kuasa kaum lelaki dan kuasa kaum feodal. Namun demikian, di dalam novel, penulis juga menampilkan citra perempuan yang sama sekali baru dan berbeda dari citra perempuan kebanyakan. Yaitu, perempuan dengan semangat perlawanan untuk menentang kategori sosial yang diskriminatif terhadap identitas (perempuan).

Keywords: discrimination; female identity; gadis pantai; identity formation; traditional Java.

\section{Introduction}

Pramoedya Ananta Toer's fictions are increasingly popular among both Indonesian and international critics and readers for they provide a discourse of the country's history with fascinating force. His Gadis Pantai, translated as the girl from the coast, is specifically concerned with patriarchal and feudal experiences that discriminate women at the $20^{\text {th }}$ century Java, the most developed, the most colonized, and the most densely populated island in the country (Locher-Scholten 2000). Though the novel exhibits the coexistence of Dutch colonial nexus, racial discrimination is not very much shown. It focuses more on sexism and classism in the $20^{\text {th }}$ century Java.

Proposing privilege and poverty as the theme, the novel uncovers the life of an aristocrat's wife. Its main female protagonist 
called simply the girl is forced to leave her parents and fishing village behind and move to the city to become the lady of her husband's house. However, after the girl becomes pregnant, she realizes that she is merely a practice wife. She is not only discarded but also separated from the child she carries. The patriarchal feudal system in traditional Javanese society discriminates women in the public eye.

Gadis Pantai is apparently intended as the first manuscript of the trilogy concerning the rise of Indonesian nationalism, while the girl's extraordinary story is based on the story of Pramoedya's grandmother marital life. Meanwhile, the second and third manuscripts were lost on political vandalism in Indonesia in 1965, and until now they could not be found (Toer 2000). Apart as a family romance, the trilogy is also a national struggle romance as well as a socio-political romance. However, in 1987, the Attorney General of the New Order regime also suppressed the publication of Gadis Pantai along with Sang Pemula, both of which are seen as propagating Marxist-Leninist ideology prohibited by the regime (Toer 2000, vii).

Studies with reference to Gadis Pantai have been conducted by some writers from various perspectives. Perwitasari and Hendariningrum (2009), for instance, see the novel as a political text representing the author's ideology. The author uses the novel as media to transfer his thoughts and ideology to change social construction in Javanese society. Meanwhile, Dara Windiyarti (2017) sees the novel as an objectification of women by men. This objectification, locating women as an object and men as the subject, according to her, has always led to violence that makes women find themselves difficult to rise. Supriyadi (2005) analyzes Gadis Pantai from the concept of androgyny, a branch of feminism which attempts to bridge between men and women relations. However, he argues that the marriage between the 
main protagonist of the novel named the girl and her master is not sort of androgyny for there is no harmony between the two.

Next, Dewi (2007) looks at the novel with postcolonial framework, i.e. an interaction between imperial legacy and local wisdom. She finds its female protagonist has an individual voice that cannot be reduced into one single voice as that of the Third World Women. Last but not least, a comparative study of Pramoedya's Gadis Pantai was conducted by David Raybin (2009) from Eastern Illinois University. He analyzes the novel from the politics of gender and religion. He claims the novel to have a plot line and authorial stance that in many ways parallel those of Chaucer's Clerk's Tale. Both works display a particular interest in a peasant woman's opportunities for agency in a noble household where the practices of institutionalized religion sustain the husband's authority.

This study tries to offer a new outlook of the politics of identity focusing on the complexity of what forms female identity. It uses identity theories and feminist discourses to explain the plight of Javanese women at the beginning of the 20th century as described in the novel. The study employs an interpretive analysis and close reading of the novel; that is, it concentrates on specific details of the text in order to see some deeper understanding present in it. The details will be supported with specific examples from the text in the form of quotations or cited paraphrases. The answer for the focus of this study matters because it affects what the women do and how they react to the circumstances in which they find themselves.

\section{Identity and Its Formation}

Identity is a multifaceted construct difficult to conclusively define (Schachter and Rich 2011). Although the term is frequently found in various discourses, such as ethnic, religious and other social entities, it is still difficult to provide an adequate state- 
ment representing the scope of its meaning. Indeed, the concept of $i d e n t i t y$ in social science context is broader than that in daily context (Fearon 1999). A simple question of what identity is seems to be identical with who you are. Here, one might answer such a question differently according to different circumstances, such as a Muslim, a professor, a native, a humanist, a moralist, a writer, and so on. The person's identity is then how the person defines who she or he is.

Some formulations of $i d e n t i t y$ have been given by social scientists. Oyserman et al., for example, stated that identity is the characteristics, social relations, roles, and social group memberships that exactly describe who one is. They may refer to the past-what used to be true of one, the present-what is true of one now, and the future-the person one expects to become (Oyserman, Elmore, and Smith 2012). Identity, hence, isn't a fixed marker people believe it to be but is dynamically constructed. Labels received by individuals or groups are temporary and changeable.

Vignoles et al. (2011) revealed that identity is usually classified into three different types, namely individual, relational, and collective. These three types denote both forms of identity and processes by which identity is formed, maintained, and changed over time. Individual identity, for example, is understood to refer not only to personal values, goals, beliefs, standards for behavior, and so on, but also to the participative role of the individual in expecting and forming his or her own identity (Vignoles, Schwartz, and Luyckx 2011, 3). In this sense, the individual becomes the center of attention. Relational identity, on the other hand, looks at one's role in relation to other people. This form of identity includes roles such as teacher, student, rector, advisor, etc. Important to remember is that these roles also deal with how they are defined and understood by individuals who 
assume them; this relational identity needs recognition from social audience. Finally, collective identity is defined as people's identification with the group or social categories to which they belong. This identity is related to a person's membership in any form of social groups, such as ethnicity, nationality, religion, gender, etc. (Vignoles, Schwartz, and Luyckx 2011, 3).

In addition to those three types of identity, William James mentions that identity may also be based on material objects. By material objects, he means that the contents of a person's identity can include not only the mind, body, friends, ancestors, and descendants, but also things like clothes, house, car, and bank account. Thus, beyond individual, relational, and collective identities, people may also be said to have a material identity. Taken together, they can provide the basis for an integrated operational definition of identity (Vignoles, Schwartz, and Luyckx 2011, 4).

Michael Hecht, who developed the communication theory of identity in the 1980s with his colleagues, conceptualized identity as communication. Social roles and relations of the individuals, according to him, are formed by and internalized through communication. He proposes the four intertwined frames of identity where communication plays its crucial role, i.e. personal, enacted, relational and communal identities. The personal frame is the individual's self-concepts; the enacted frame is the individual's performed or expressed identity; the relational frame exists in relationship to each other; and the communal frame transcends individuals and is a characteristic of the group or collectivity (Littlejohn and Foss 2008). However, Hecht believed that identity is also something enduring. At this point, he identifies the four dimensions of identity, namely feelings (affective), thoughts (cognitive), actions (behavioral), and a sense of relation to the transcendent (spiritual). These all-encompassing dimensions, according to Hecht, can serve as a staying power, source of moti- 
vation and expectation people have in life (Littlejohn and Foss 2008). Therefore, although identity is never fixed and always emergent, there is a core of a stable identity.

Similarly, the face negotiation theory by Stella Ting-Toomey explained that identity is constructed from communication in various cultural settings. Ting-Toomey asserts that identity is negotiated through social interaction; that is, when people communicate within and between cultural groups. By negotiation, she means that identity can always be called into question (Griffin 2012). This social interaction first occurs early in family life, where the family members start to identify and internalize various personal and social identities (Littlejohn and Foss 2008, 90). It is in the family where the initial gender identity also develops and subsequently becomes a very important part of social identity.

The interaction between cultural groups proposed by TingToomey also deals with ethnicity or ethnic identity. Ethnic identity is a form of association with the past ancestors across generation. It includes national origin, race, religion, and language (Littlejohn and Foss 2008, 91). Ethnic identity can be a crucial part of who one is or groups of people are. People gain their identities through interaction with various social groups of which they are a part, e.g. family, community, dominant ideologies, etc.

The above mentioned explanation suggests that identity is basically politicized; it is socially constructed. No identity exists outside the social construction. This means that one's identities are always dynamic, as he or she responds to the contexts and situations around him or her. In this sense, politics of identity is seen as a way to adjust identities in motion. Identities are, then, moment-by-moment performances that are able change (Littlejohn and Foss 2008, 93). In line with this, queer theory proposed by Judith Butler, for instance, sees the formation of 
gender and sexuality as fluctuating and evolving productions or performances rather than stable, essential, unchanging categories. The theory is developed to construct, establish, and (re)produce standards used to assess goodness, morality, and superiority in a cultural system (Littlejohn and Foss 2009).

Equally important is Julia Wood's standpoint theory that explains how circumstances of the individual's life affect how he or she views, understands and constructs a social world. According to this theory, social conditions alone do not construct the social world, but the individual's distinctive ways do (Littlejohn and Foss 2008, 92). Here, women's identity is earned through conversion into a new form of existence and through critical reflection on power relations of the oppressed and the oppressor to construct an oppositional stance.

\section{Contextualizing the $20^{\text {th }}$ Century Java}

The very beginning of the novel narrates a daughter forcibly removed from home by her father to marry to a lord known as bendoro, a wealthy religious advisor to a regent in the city of Rembang. The daughter is not named and is identified as merely the girl, showing an insignificant position of women in patriarchal society. The marriage between the girl and the lord is arranged and brokered through the girl's father, who feels no choice but to take the opportunity. The girl follows her father's command to marry without objection. She becomes so powerless to resist, and her identity is politically kept submerged in a situation in which critical awareness and response seem impossible (Freire 1985).

At the turn of the $20^{\text {th }}$ century Java, practices of arranged marriage-or forced marriage if you will-between local lords and villagers were quite common (Kartodirjo 2001). Parents arranged a marriage of their young daughters, preferably with a man from higher social class. Being married by a man from 
noble family was an extraordinary chance for both parents and daughter because it could not only bring the parents in a place of honor in the community but also lead to a better life for the daughter. In the girl's case, the father expects a better future for the daughter and, at the same time, takes benefit from her new status though he has married his daughter to a man about whom she has no idea. Her personal values and goals are silenced by the male domination.

Traditional society of the colonial time suggests that economic, political, and cultural norms can constitute an ideological framework that controls women's bodies (Katrak 2006) and identity. There we find, among men and women, a gap of power distribution that leads to women discrimination. Women's voices are politically suppressed in a world controlled by men. They are prevented from defining their own identity and determining their own destiny. Men, in the other hand, possess the power to change women's life for better or worse. In the novel, we can see that the father controls all family members and economic resources, and makes all major decisions in the family.

The girl's marriage is indeed a form of discrimination and oppression by the parents. The parents neglect the girl's aspiration to marry whom she likes and to live where she wants. They try to impose their desire to achieve personal benefits, such as honor and properties. The father interrupts the daughter's basic rights, and this interruption should be seen as a system of male domination (Walby 1989). Her rights are wiped out by his bad temper, and her possible reaction is only to keep silence. This static response, however, signifies her active adaptations (Katrak 2006, 12) to the father's temper, which is most of the time unpredictable. Therefore, the girl's departure to the city marks a defeat of female identity. 
Women are so inferior that they must follow whatever the men do. Years of feudalism have frozen the women into a fixed pattern of surrender and obedience to the men. The fate has been set for them; their identity has been shaped. That is, to serve their men, regardless whether they are happy or not with it. They have to learn to please their men. As we read the novel, a line maintaining this inferior position is clear; the mother advises the girl to always be in obedience to her husband for it has been a matter of fate. The mother, for instance, said:

"A woman must be with her husband. That is the way it has been for me," the mother consoled. "It does not matter if you live in a rundown shack or whether or not you are happy; you have to learn to please your man.” (Samuels 2002)

The line explains that since the girl has become someone's wife, she must try to live an independent life from her parents. She must begin to think of her husband, obey all his orders, and make him happy.

Furthermore, a marriage between two different social classes in feudal Java is remarkable only for the lower class, not the upper class. The novel tells that the girl's marriage is not directly with the bendoro, but a dagger representing her husband-to-be. In this sense, a marriage ceremony may be done even in the absence of the man. In other words, proxy either by human agents or even by objects can hold the marriage. This segment portrays how the power of the noble man exercises the commoners. A man from the upper class can impose his will without considering the human values of equality and equity in society. Indeed, the traditional Java imposes a very rigid social stratification between the upper and lower classes (Koentjaraningrat 2002).

The power transmission from the lower class to the upper class is displayed in the next scene. Feeling troubled and nervous to bendoro's servants and great mansion, the father, symbol of 
power of the family, is forced to admit a more commanding power, i.e. the bendoro (Samuels 2002,9). This transmission interestingly portrays how the Dutch (the upper class) imposed their will on the Indonesians (the lower class) and made them impotent (Hill 2011). It can serve as a metaphor that tells about the way the Dutch arrived on the coasts of Indonesia and immediately established themselves as an incomprehensible superior force requiring unquestioning obedience.

Later, following the new status as the bendoro's wife, the girl converts from the lower class to the upper class. Her identity is systematically shaped to conform to the life of nobility, which, according to her, violates her basic rights as human. Indeed, her new status separates her from her parents because it removes her rights and obligations as a daughter to her parents. The relationship between the daughter and the parents is no longer daughter-parents ties, but more like the master and her maidservant. The girl, for instance, cannot meet and talk at anytime to her own mother, who for a couple of days must accompany her in the bendoro's mansion (Samuels 2002, 78).

A large part of women's discrimination is seen when, after more than a year, the girl asks her servant where the bendoro usually goes, leaving her alone at the mansion. The patriarchal ways of the elite are "That is a man's business, Young Mistress. And it would be best for you not to interfere. Women do not know about such things. Our work is here in the house. This is our territory, the area under our control" (Samuels 2002, 74). This ways, according to the girl, are so different from those in her village where husbands and wives quarrel freely. When she asks directly about this, about why husbands and wives in the city do not speak, and about what a city wife might own, the servant's answer is succinct: "Nothing, Young Mistress. She herself is property” (Samuels 2002, 84). 
The girl's identity in the eyes of bendoro is no more than that of a maidservant and property. In his house, she has to make sure that the house is always clean. Besides, she must practice the manner of a maidservant in front of him. For example, at anytime after the Bendoro gives instruction to the girl, she has to press her palms and fingertips together to her forehead, then bow and move backwards a distance in squatting position to leave the room (Samuels 2002, 244). Feudalistic institution requires the commoners to always sit on the ground before their master (Kartodirjo 2001, 145).

The girl gradually realizes that neither she nor all the maidservants can contest the superiority of the bendoro and his relatives. The commoners cannot blame the noblemen how true the commoners are. Blaming the noblemen, like the bendoro and his relatives, can mean rejecting the God's decision, and it is considered blasphemy, not grateful to God. The case of the missing wallet in the novel has proven this argument.

The end part of the novel reveals that a few months after the girl returns to the city from a short visit to her village, she is pregnant and gives birth to a baby girl in the absence of the bendoro. Unfortunately, a son is more desired by him than a daughter (Samuels 2002, 256). Hence, he never comes to see the Girl's daughter. Finally, at the narrative's climax, the bendoro brusquely instructs the girl to return home in the village without her three-month-old daughter. The bendoro divorces her but keeps the baby, forbidding her to ever attempt to contact him or the child again. In traditional Java, divorce by the man through repudiation (talāq) was relatively easy (Locher-Scholten 2000, 189). Holding out a small cloth bag heavy with coins, the bendoro says to his practice wife:

"This is for you. Find yourself a good husband and forget you've ever been here, in this house. Do you understand what I am telling you?” (Samuels 2002, 260) 


\section{Women and the Search for Self-Identity}

The girl's marriage with the bendoro in Gadis Pantai is a form of woman's discrimination done by the father. Through the marriage, the father expects his daughter to be a wealthy woman and have high social status, so that it will eventually raise his status among the villagers. In contrast, the girl is very sad to leave her village though it is dirty, and the people are poor. However, she has to obey her parents, especially the father. Here, in a world where men have access to control women's outerbody, the only space left for women is their inner-body.

Silence and crying are the most common way shown by the girl who is unable to resist the will of the parents. Both are the traditional resistance that uses female body in the form of acceptance or passive agency, a term used by Ketu Katrak (2006, 15 ), to counter male domination (Katrak 2006, 56). Silence and crying can represent the girl's inner voice. However, it turns out that a protest through silence and crying is a futile act since the parents' will is considered more powerful. Finally, she has to go to the city as a form of obedience to her parents. Kartini describes women's life in traditional Java:

“... is quiet and tacticum, motionless, like a wooden doll ... speaks only when absolutely necessary, whispering so that even the ants are unable to hear ... walks like a snail ... laughs without opening his lips" (Toer 2012).

In addition, the girl also uses an ironic statement criticizing her mother's view about the quality of the dress given by her husband-to-be, i.e., a piece of expensive batik. According to the mother, the girl should be thankful that she could have such kind of luxurious dress. The frustrated girl's reply is "then take it". She also points at the necklace, earrings, and bracelet, and satirizes that if the expensive dress, necklace, earrings, bracelet and so on are the reason of her removal from her village and 
beloved people, she will let her mother remove them all from her body for she neither needs nor expects to have them. She wants to live a life based on her own choice.

As the Girl begins to live in the bendoro's mansion, she has to adapt to the life of nobility. She has to live a life in accordance with the bendoro's desires. She feels very strange in her new place, like a chick being removed from its flock and having to live alone with no friends among a group of strangers. However, if it is fear she feels, then she no longer knows the meaning of the word. She is too afraid to think, too afraid to even cry (Samuels $2002,25)$. She has no power to resist because she does not even know what to resist, as if some mysterious force in the house has commanded her. She is in total submissiveness to the bendoro, her master.

In the Bendoro's house, for example, slowly the girl begins to understand that she can never address anyone as her equal. The two lives have been set up, i.e. the life of the upper class and the life of the lower class; the life of the noble men and that of the commoners. A nearly unbridgeable barrier has been erected between them, and thus between herself and the servant. Accordingly, she cannot meet her own mother at anytime she wishes, for she is now a noble lady, while the mother is a commoner. She questions and challenges this ways of nobility: 1The scene describes how the girl refuses to be subservient to the rule disallowing her to meet and sleep with her own mother merely because the mother is a commoner. She argues that the mother must not be treated like a servant. This open rebellion portrays her resistance to the ways of nobility (Katrak 2006, 62). Finally, she comes to realize that in the house are only orders and commands. To resist against her husband, her master, can mean opposing the fate predetermined upon and, thus, rejecting God's decision (Samuels 2002, 58). 
Finally, we come to see how the power of the upper class exploits the protagonist's reproductive value. The girl is sent back to her father's house, with only the clothes she is wearing. This part of the novel narrates the moment the bendoro summons the father of his practice wife to take her home, and she dares to inquire about the raising of their daughter. Although the question is phrased timidly, as she has not yet understood that she is to lose her child and still is calm, the bendoro responds with annoyance. He informs her that he has given her father compensation, and admonishes her to "forget you've ever been here, in this house ... You are to forget you've ever known me!" (Samuels 2002, 260).

As a sixteen-year-old bride, the girl does not possess apparent emotional strength. The novel exposes the three years of marriage during which she has suffered, matured, and educated herself through experience. She now recognizes what it is that she values. Her father tells her to be glad because the baby girl that she carries will be raised in a wealthy household, even as he shares in her grief and begs forgiveness for having married her to a man who does not love his children. The father, standing beside the girl feeding his granddaughter, says:

"I'm so sorry," he mumbled. "I never thought it would turn out like this."

The Girl looked up into his eyes. "You are a good man, Papa. You didn't do anything wrong."

"But you are crying."

"And you are, too."

"I was stupid, such a fool. Can you forgive me?" he asked his daughter again."

"But there is one thing," he added. "This granddaughter of mine will be a noble, not like one of us." (Samuels 2002, 26263) 
However, when a father will not take up his child in his own hands because that is a servant's task, maternal obligation explodes, regardless of the personal cost: "I am this baby's mother. If her father will not even hold her or take care of her, then I will take her home to the village" (Samuels 2002, 266).

The novel's climactic scene has the Bendoro seated with an open copy of Quranic interpretations in his hand (Samuels 2002, 265). When he informs the girl whom he has just summarily divorced, and he is going to retain her 3-month-old daughter, she cries out not only against the feudal and patriarchal sovereignty that permits his behavior, but also against his spiritual authority (David Raybin 2009, 194).

"Even a hen will protect its chicks, Sir. And you are talking to me, a human being-even if I can't recite scripture at the mosque!" (Samuels 2002, 266).

This narrative plays against the bendoro's religious practices as he has made the pilgrimage to Mecca twice already and frequently read the entire Quran (Samuels 2002, 7).

The girl's transformation to gain self-awareness and selfempowerment, i.e. self-identity, demands a profound rebirth. It is until she cannot tolerate the unbearable contradictory values in the life of nobility, she discovers that the Bendoro, her husband, is her oppressor, and in turn retrieves her consciousness (Freire $1985,61)$. She takes on a new form of existence by voicing out the corrupt practices of the noble men in front of her father and the Bendoro. Later, she decides to leave her baby girl and the town but does not go back to her village. The novel concludes with the girl living in another town where she can start a new life.

\section{Conclusion}

Female identity is a social construct dynamically negotiated through social interaction. It initially occurs in family setting, 
in which the family members start to acquire various personal and social identities. In the early twentieth century Java, female identity is shaped by the feudal and patriarchal power. Women are intentionally denied to access to rights, opportunities, and resources fundamental to social integration; they are required to meet the needs of the dominating power.

This argument is well depicted in Pramoedya A. Toer's Gadis Pantai that exposes a female protagonist, called simple the girl, who struggles for self-identity. Experiencing a forced marriage locating woman as an exchanged object, the girl becomes the victim of patriarchal ambition in the pursuit of wealth, status, and position. Virtue and obedience become her important characteristics representing women of traditional Java in general. The girl's fate gets worse when finally she must marry to a man about whom she has no idea. Indeed, in traditional Java, a man from aristocratic family can conduct a marriage with a girl from poor family even in his absence. Proxy, either by human agents or even by objects, can hold the marriage. In the novel, the girl, as a practice wife of a feudal lord, must follow the ways of nobility which require her to treat her own parents as her servants or slaves. The girl frequently questions the values she considers unreasonable. She criticizes the hypocrisy of the upper-class members in feudal Java who do not conform the moral standards they believe, and instead use their power to exploit the lower class.

At this point, Pramoedya's female protagonist cries out a universal desire for freedom, justice, and personal opportunity. In fact, she is not encountering her father and her husband, but a system prevailing in Javanese society. Therefore, her struggle for self-identity should be understood as a struggle to trouble the feudal and patriarchal objectification and definition of female identity in traditional Java. 


\section{Bibliography}

Dara Windiyarti. 2017. "Novel Gadis Pantai Karya Pramoedya Ananta Toer: Objektivikasi Perempuan Oleh Laki-Laki." Semiotika 18 (1): 1-13. doi:10.19184/semiotika. v18i1.5180.

David Raybin. 2009. "Muslim Griselda: The Politics of Gender and Religion in Geoffrey Chaucer's Clerk's Tale and Pramoedya Ananta Toer's The Girl from the Coast." Exemplaria 21 (2): 179-200. doi:10.1179/175330709X406401.

Dewi, Novita. 2007. "Every Book Has a Voice: A Postcolonial Reading of Gadis Pantai and Larasati." Asian Englishes 10 (2): 82-91. doi:https://doi.org/10.1080/13488678.2007.1 0801214.

Fearon, James D. 1999. What Is Identity (As We Now Use the Word)? California: Stanford University.

Freire, Paulo. 1985. The Politics of Education: Culture, Power, and Liberation. South Hadley: Mass Bergin \& Garvey.

Griffin, Emory A. 2012. A First Look at Communication Theory. New York: McGraw-Hill Companies.

Hill, Lisa. 2011. "Review of The Girl from the Coast : A Novel." ANZ. http://anzlitlovers.com/2011/03/17/the-girl-fromthe-coast-by-pramoedya-ananta-toer-translated-by-willem-samuels/.

Kartodirjo, Sartono. 2001. Indonesian Historiography. Yogyakarta: Kanisius.

Katrak, Ketu H. 2006. Politics of the Female Body: Postcolonial Women Writers of the Third World. New Brunswick, NJ, and London: Rutgers University Press.

Koentjaraningrat. 2002. Kebudayaan Jawa. Jakarta: PN Balai Pustaka. 
POLITICS OF FEMALE IDENTITY IN TRADITIONAL JAVA

Littlejohn, Stephen W., and Karen A. Foss. 2008. Theories of Human Communication. Belmont: Thomson Wadsworth.

- 2009. Encyclopedia of Communication Theory. California: Sage Publications Inc.

Locher-Scholten, Elsbeth. 2000. Women and the Colonial State: Essays on Gender and Modernity in the Netherlands Indies 1900-1942. Amsterdam: Amsterdam University Press. doi:10.5117/9789053564035.

Oyserman, Daphna, Kristen Elmore, and George Smith. 2012. "Self, Self-Concept, and Identity." In Handbook of Self and Identity, edited by M. R. Leary and J. P. Tangney. New York: Guilford Press.

Perwitasari, Maria Endah, and Retno Hendariningrum. 2009. "Analisis Wacana Kritis Feodalisme Dan Diskriminasi Perempuan Jawa Dalam Novel Gadis Pantai Karya Pramoedya Ananta Toer." Jurnal Ilmu Komunikasi 7 (3): 212-27. doi:http://jurnal.upnyk.ac.id/index.php/komunikasi/article/view/25/26.

Samuels, William. 2002. The Girl from the Coast (TGFC): A Novel. New York: Hyperion.

Schachter, Elli P., and Yisrael Rich. 2011. "Identity Education: A New Conceptual Framework for Researchers and Practitioners." Educational Psychologist, 46(4), 46 (4): 222-238. doi:10.1080/00461520.2011.614509.

Supriyadi. 2005. "Humaniora." Humaniora Volume 17 (No. 2): 195-203. doi:https://jurnal.ugm.ac.id/jurnal-humaniora/ article/view/845/692.

Toer, Pramoedya Ananta. 2000. Gadis Pantai. Jakarta: Hasta Mitra.

—. 2012. Panggil Aku Kartini Saja. Jakarta: Lentera Dipantara. 


\section{MUHAMMAD JAUHARI SOFI}

Vignoles, Vivian L., Seth J. Schwartz, and Koen Luyckx. 2011. "Introduction: Toward an Integrative View of Identity." In Handbook of Identity Theory and Research, 1-27. New York: Springer. doi:10.1007/978-1-4419-7988-9_1.

Walby, Sylvia. 1989. “Theorising Patriarchy.” Sociology 23 (2): 213-34. doi:10.1177/0038038589023002004. 